\title{
STABILITY EVALUATION OF TARTRAZINE BY LIQUID CHROMATOGRAPHY-DIODE ARRAY DETECTOR AND HIGH-RESOLUTION ELECTRON SPRAY IONIZATION QUADRUPOLE TIME-OF- FLIGHT MASS SPECTROMETRY/MASS SPECTROMETRY ANALYSIS
}

\author{
KRISHNAVENI NAGAPPAN ${ }^{1 *}$, KARTHIK YAMJALA ${ }^{1}$, MATHIVATHANI SATHYASEELAN ${ }^{1}$, GOWRAMMA BYRAN ${ }^{2}$
}

${ }^{1}$ Department of Pharmaceutical Analysis, JSS College of Pharmacy, (A Constituent College of Jagadguru Sri Shivarathreeshwara University, Mysuru), Udhagamandalam, Nilgiris - 643 001, Tamil Nadu, India. ${ }^{2}$ Department of Pharmaceutical Chemistry, JSS College of Pharmacy, (A Constituent College of Jagadguru Sri Shivarathreeshwara University, Mysuru), Udhagamandalam, Nilgiris - 643 001, Tamil Nadu, India. Email: krisath@jssuni.edu.in

Received: 19 January 2017, Revised and Accepted: 15 April 2017

\section{ABSTRACT}

Objective: This study investigates the degradation behavior of tartrazine, a synthetic azo dye used in pharmaceutical products.

Methods: For this purpose, standard solutions containing E102 were subjected to $\mathrm{pH}$, oxidation, photolytic conditions and were analyzed by the developed high-performance liquid chromatography (HPLC) method.

Results: The results show degradation in standard solution with the formation of single degradation product in oxidative visible light condition. The formed unknown degradation product was isolated by semipreparative HPLC and characterized using ultra-HPLC coupled with high resolution tandem mass spectrometer (MS).

Conclusion: The isolated component was vacuum dried and subjected to high-resolution MS analysis for the plausible structural elucidation. Based on the fragmentation pattern of one degradation product (ODP) from their MS $^{\mathrm{n}}$ studies, the ODP may be identified as 2,5-dihydroxy-1-phenyl-3(phenyldiazenyl)-2,3-dihydro-1H-pyrazole-4-carboxylic acid.

Keywords: Tartrazine, Degradation, High-performance liquid chromatography, Validation, Mass spectrometry.

(c) 2017 The Authors. Published by Innovare Academic Sciences Pvt Ltd. This is an open access article under the CC BY license (http://creativecommons. org/licenses/by/4. 0/) DOI: http://dx.doi.org/10.22159/ajpcr.2017.v10i7.17191

\section{INTRODUCTION}

The color of pharmaceutical products significantly affects consumer choice as it is helpful in distinguishing the products of the same drug with various dosage forms. Several colorants are therefore added to pharmaceutical products for coating tablets, in semisolid and liquid preparations and also in coloring core tablets. They are used for making them more visually esthetic to consumers and to reinstate their original appearance when it has been lost during production processes. Pharmaceutical colorants can be either natural (carotenoids, annatto, cochineal extract, and grape color extract) or synthetic (tartrazine [TA], sunset yellow FCF, and brilliant blue FCF) in origin. Synthetic dyes are more stable and less expensive when compared to dyes of natural origin [1].

Synthetic dyes can undergo degradation in the presence of various environmental conditions with the formation of potentially toxic products. In particular, azo-dyes $(-\mathrm{N}=\mathrm{N}-)$ which constitute around $65 \%$ of all dyes employed in food and textile industries [2] can be decomposed by natural intestinal flora to aromatic amines which can cause asthma and allergic hypersensitive reactions [3]. For this reason, many countries have banned the majority of azo dyes usage in pharmaceuticals. Legislations on colors are highly regulated for domestic and export supplies, for example, Food and Drug Administration (FDA) [4] in the United States, European community regulation [5] for European countries, and Food Safety and Standards Authority of India in India [6]. These legislations lists the dye permitted in pharmaceuticals and provides the maximum allowable limits but do not specify the information on dye stability toward environmental conditions ( $\mathrm{pH}$, sunlight, and oxidation).

TA, also known as E102, FD\&C yellow No. 5, acid yellow 23, C.I. 19140 is chemically trisodium (4E)-5-oxo-1-(4-sulfonatophenyl)- 4-[(4-sulfonatophenyl)hydrazono]-3-pyrazole carboxylate a lemon yellow azo dye (Fig. 1).

It is one among the certified color additives that are permitted for use as drug colorant for internal consumption, external use and around the eye area approved by U.S. Food and Drug Administration (FDA). Over the counter and prescription drugs that contain TA shall bear statements on the label stating that the product contains FD\&C yellow No. 5 as a color additive and they may cause allergic-type reactions (including bronchial asthma) in certain susceptible persons. It is also associated with hypersensitivity reactions which include headaches, asthma attacks, itching or hives, insomnia, and hyperreactivity $[7,8]$. Furthermore, a study had reported the structure alteration of the intestine, spleen, and thymus cell damages as well as depressing effect on the humoral immune response in make mice on subchronic ingestion of $1 \%$ TA [9]. Stability evaluation of dyes is a part of development strategy and is normally carried out under severe conditions such as $\mathrm{pH}$, oxidative environment, and sunlight which enables in recommending the preferred storage conditions and establishing its shelf life. The degradation species formed during stability evaluation could be even more toxic than that of parent dye [10].

Relatively few analytical studies of TA are present in the literature [11-18]. The photo-degradation of C.I. acid yellow 23 in the presence of $\mathrm{ZnO}$ and $\mathrm{TiO}_{2}$ has been studied $[19,20]$. Many of the degradation studies for the approved colors are carried out in model solutions and food products/beverages. The degradation of few food dyes along with the characterization of their degradation impurities has been reported in model solutions as well as beverages by employing liquid chromatography and mass spectrometry (MS) [21-28]. Saad Antakli and coworkers have developed a spectrophotometric 
method for the simultaneous determination of TA and brilliant blue in foodstuffs [29]. One reversed-phase high-performance liquid chromatography (HPLC) method for the simultaneous estimation of sunset yellow and TA in food products was developed in our laboratory [30]. Till date, no reports are available on the stability evaluation of TA and characterization of its degradation products under environmental stress conditions.

The aim of this study was to evaluate the stability profile of TA and also to isolate, identify the degradation products that are formed in model solutions as a result of $\mathrm{pH}$, uncontrolled sunlight, and oxidation. For this purpose, LC and LC coupled with high-resolution MS/MS seemed the most appropriate analytical tool. The data obtained from highresolution (HR) MS provides accurate mass measurements which could be useful for predicting the degradation pathway of TA.

\section{METHODS}

\section{Chemicals}

Acetonitrile and methanol (>99.8\%) are of HPLC and LC-MS grade (Merck, Mumbai, India). TA ( $>90 \%)$, ammonium acetate ( $>99.8)$, and acetic acid (>99.8) were purchased from Sigma-Aldrich (St. Louis, MO, USA). Hydrochloric acid, sodium hydroxide, and hydrogen peroxide are of analytical grade supplied by SD Fine Chemicals (Mumbai, India). Ultra-pure water from Milli-Q water purification system (France) was used.

\section{Instrumentation}

Stability studies and peak purity experiments were investigated using Shimadzu gradient HPLC system equipped with LC-20 AD pump, SPDM20A PDA detector with $20 \mu \mathrm{L}$ of loop volume. LC-MS experiments were carried out on Shimadzu HPLC system equipped with LC-20 AD pump, SPD-M20A PDA detector, Electronspray ionization-quadrapole (ESI-Q) MS equipped with an SIL-20AC autosampler. A Phenomenex (Kinetex) $\mathrm{C}_{18}(150 \times 4.6 \mathrm{~mm}$, id, $5 \mu \mathrm{m})$ stationary phase was used to separate all the compounds. The data acquisition and processing for HPLC and LC-MS were performed using Lab Solutions software. LCMS/MS studies and accurate mass measurements were carried out by 1290 infinity ultra HPLC-Q-time of flight (TOF) (6550 iFunnel Q-TOF) MS (Agilent Technologies, USA) equipped with ESI source. The data acquisition was under the control of Analyst ${ }^{\circledR}$ QS software.

\section{Stability evaluation}

Stability evaluations of TA (1 mg/mL) were carried out under hydrolysis (acid and base), oxidation and photolytic conditions which were commonly encountered during storage and transportation. Acid and base hydrolysis were carried out in $0.1 \mathrm{M}, 1 \mathrm{M}$, and $5 \mathrm{M}$ strengths of $\mathrm{HCl}$ and $\mathrm{NaOH}$ for $24 \mathrm{hr}$, respectively. The oxidative degradation study was carried out with 3 and $30 \% \mathrm{H}_{2} \mathrm{O}_{2}$ for $24 \mathrm{hr}$. The TA in solution form was exposed to ultraviolet (UV) $(254 \mathrm{~nm})$ and visible light (with and without $\mathrm{H}_{2} \mathrm{O}_{2}$ ). All the samples were withdrawn at regular time intervals and diluted $10 \times$ with mobile phase and stored at $-20^{\circ} \mathrm{C}$. The solutions were filtered through $0.22 \mu \mathrm{m}$ filter before analysis.

\section{Chromatography and MS conditions}

A Kinetex $\mathrm{C}_{18}(150 \times 4.6 \mathrm{~mm}$, id, $5 \mu \mathrm{m})$ was used with mobile phase consisting of water and acetonitrile in an isocratic mode $(50: 50 \%, \mathrm{~V} / \mathrm{V}$ ) pumped through the column at a flow rate of $1.0 \mathrm{~mL} /$ minute with an injection volume of $20 \mu \mathrm{L}$. The eluents were monitored at $426 \mathrm{~nm}$. Semipreparative Isolation of one degradation product (ODP) was carried out with same mobile phase on Zorbax Bio Series RP-C ${ }_{18}(250 \times 9.0 \mathrm{~mm}$, id, $5 \mu \mathrm{m}$ ) stationary phase with a flow rate of $5 \mathrm{~mL} /$ minutes and injection volume of $100 \mu \mathrm{L}$

For MS analysis, all the samples ( $5 \mu \mathrm{L})$ were injected directly into the source by flow injection method using ammonium acetate $(0.05 \mathrm{M}$, $\mathrm{pH} 4.5$ adjusted with acetic acid) and acetonitrile (50: $50 \mathrm{~V} / \mathrm{V})$ as mobile phase at a flow rate of $0.4 \mathrm{~mL} /$ minutes. The MS were recorded in ESI negative mode for both TA and ODP. High purity nitrogen and helium were used as curtain and collision gas, respectively. The typical ion source conditions were: Nebulizer gas, 60 psi; dry temperature, $350^{\circ} \mathrm{C}$; dry gas, $10.0 \mathrm{~mL} /$ minutes; capillary voltage, $4.5 \mathrm{kV}$; capillary current, $81.787 \mathrm{nA}$; vaporizer temperature, $400^{\circ} \mathrm{C}$ and dwell time, $200 \mathrm{~ms}$. For the collision-induced dissociation (CID) experiments, the precursor ion was selected using quadrapole (Q) analyzer and productions were analyzed by TOF analyzer. HR MS data acquisition was performed by the following source conditions: Capillary voltage, $5 \mathrm{kV}$; declustering potential and the collision energy were $-50 \mathrm{~V}$ and $-10 \mathrm{~V}$, respectively; focusing potential, $220 \mathrm{~V}$; resolution 10,000 (FWHM).

\section{RESULTS}

\section{Method validation}

The developed HPLC method was validated as per ICH guidelines in terms of sensitivity, linearity, specificity, accuracy, instrument precision [31], and data are summarized in Table 1 . The sensitivity of the analytical method was determined in terms of detection and quantification limits (LOD and LOQ) which represent the concentration of analyte that would yield an S/N of 3 for the LOD and 10 for the LOQ and were found to be 1 and $3 \mu \mathrm{g} / \mathrm{mL}$, respectively for TA. A good linearity was observed for TA in the concentration range of $4-100 \mu \mathrm{g} / \mathrm{mL}$. The linear regression equation and correlation coefficient $\left(\mathrm{r}^{2}\right)$ were $\mathrm{y}=16889 \mathrm{x}+18258$, 0.996 , respectively. The specificity of the method was determined by injecting degradation solution of TA. The dye was well separated from ODP, and the method was found to be specific. The peak purity studies were performed on LC equipped with diode array detector (DAD) and

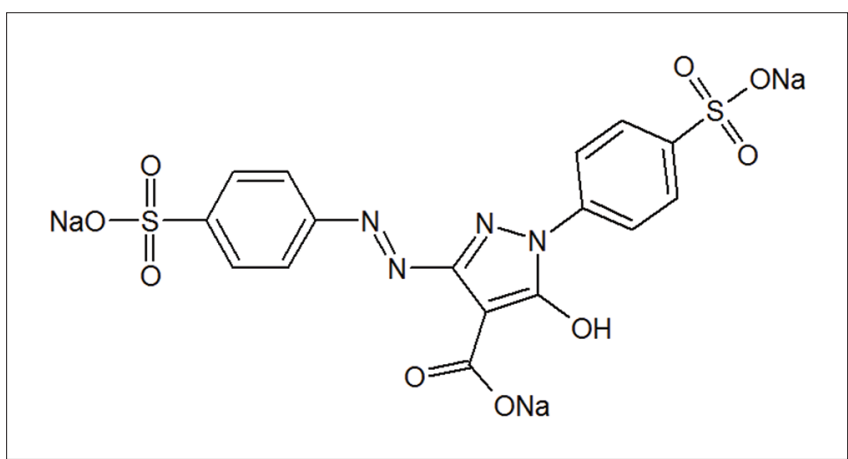

Fig. 1: Chemical structure of the dye tartrazine, E102 (molar mass: $534.3 \mathrm{~g} / \mathrm{mol}$ )

Table 1: Validation data

\begin{tabular}{ll}
\hline Parameter & Tartrazine \\
\hline Accuracy $(\%$ mean recovery \pm SD; \% CV) & \\
$\quad$ Level Ax & $24.89 \pm 0.49 ; 1.99$ \\
Level Bx $^{\mathrm{x}}$ & $49.48 \pm 0.55 ; 1.12$ \\
Level C & $99.25 \pm 0.82 ; 0.83$ \\
Linearity & \\
Range $(\mu \mathrm{g} / \mathrm{mL})$ & $4-100$ \\
Slope $(\mathrm{m})$ & 16889 \\
Intercept $(\mathrm{c})$ & 18258 \\
Correlation coefficient $\left(\mathrm{r}^{2}\right)$ & 0.996
\end{tabular}

Precision studies

Intra-day (\% mean recovery $\pm \mathrm{SD} ; \% \mathrm{CV}$ )

Level $A^{y}$

Level By

Level $C^{y}$

Interday ( $\%$ mean recovery \pm SD; $\% \mathrm{CV}$ )

Level $A^{y}$

Level $\mathrm{B}^{\mathrm{y}}$

Level Cy

Sensitivity ${ }^{x}$

Limit of detection $(\mu \mathrm{g} / \mathrm{mL})$

Limit of quantification $(\mu \mathrm{g} / \mathrm{mL})$

$24.55 \pm 0.59 ; 2.40$

$49.35 \pm 0.32 ; 0.66$

$99.58 \pm 0.30 ; 0.30$

$24.35 \pm 0.42 ; 1.74$

$49.15 \pm 0.54 ; 1.22$

$99.06 \pm 0.73 ; 0.74$

Concentrations: Level A $=25 \mu \mathrm{g} / \mathrm{mL}$; Level B $=50 \mu \mathrm{g} / \mathrm{mL}$; Level C= $100 \mu \mathrm{g} / \mathrm{mL}$. ${ }^{x} n=3,{ }^{y} n=6 . S D$ : Standard deviation, CV: Coefficient of variation 
were found to be 0.9991 and 0.9977 for TA and ODP, respectively. The instrument precision (intra- and interday) was assessed using three different concentrations. Six replicates were analyzed to determine the intraday precision. The procedure was repeated 6 times over 3 days to determine the interday precision. The accuracy of method was determined in terms of recovery. Three different concentrations were used and the recoveries of the dye were calculated from the difference between peak areas of fortified and unfortified degraded samples. The effect of flow rate on the resolution was studied by altering the flow rate by $\pm 0.2 \mathrm{~mL} /$ minutes. The effect of $\mathrm{pH}$ on the resolution of ODP and TA was studied by changing the $\mathrm{pH}$ by \pm 0.1 units (water $\mathrm{pH}$ of 6.9 and 7.1). The resolutions between the closely eluting peaks were greater than 1.5. Minor deliberate changes in optimized chromatographic conditions did not influenced the $\mathrm{R}_{t}$ of TA indicating the robustness of the method. System suitability parameters such as theoretical plates $(\mathrm{N})$ and tailing factor $\left(\mathrm{T}_{\mathrm{f}}\right.$ ) for dye were found to be 4563 per meter and 1.12, respectively. The ruggedness of the method was tested by different analyst on different instruments (Shimadzu and Waters HPLC). The critical parameters were assessed and found to be within limits indicating the ruggedness of the method.

\section{Stability experiments}

\section{Degradation studies of TA in standard solution}

Degradation of TA was not significant during hydrolysis (acid and base), oxidation and exposure to UV and visible light. Considerable degradation was observed in presence of UV (13\%) and visible light (79\%) under oxidative environment, which resulted in ODP. The degradation of TA in oxidative conditions in the presence of visible light showed a gradual decrease in the color intensity. A 3-D wireframe surface plot was used to represent the degradation behavior of TA under various stability conditions (Fig. 2).

The peak purity experiment results obtained from DAD confirmed that the TA peak was pure and homogeneous in all the analyzed stability samples.

\section{Isolation of ODP by semi-preparative HPLC}

The degradation impurity (ODP) with an $\mathrm{R}_{\mathrm{t}}$ of 2.45 minutes was separated by isocratic reverse phase elution mode using Zorbax Bio series RP C18 (250×9.0 mm, id, $5 \mu \mathrm{m})$ semi-preparative LC column with a good resolution. The isolated degradation impurity was re-confirmed by chromatographic analysis, the purity of ODP was found to be $99.7 \%$, and this sample was used for high-resolution tandem mass analysis.

\section{MS characterization of TA and ODP}

MS/MS of TA

The MS/MS characterization of TA was performed through the identification of the product-ions formed in the CID experiments. The MS were obtained by the direct injection of $10 \mu \mathrm{g} / \mathrm{mL}$ aqueous standard dye into the ESI source of Q-TOF analyzer.

The molecular structure of TA showed two negative sulfonated groups and one carboxylic group saturated with $\mathrm{Na}^{+}$(Fig. 1). To collect information that could be useful to identify the unknown products formed in the samples during degradation, a mass characterization experiment was performed in ESI negative ionization (NI) mode (Fig. 3a).

TA showed a molecular mass of $534 \mathrm{Da}$; the molecule provides distinct signals corresponding to three negative pseudo molecular ions at $511 \mathrm{~m} / \mathrm{z}, 489 \mathrm{~m} / \mathrm{z}$ and $467 \mathrm{~m} / \mathrm{z}$, respectively (Fig. $3 \mathrm{~b}$ and c). The peak at $511 \mathrm{~m} / \mathrm{z}$ is due to the [M-Na] $]^{-}$, whereas the peaks at $489 \mathrm{~m} / \mathrm{z}$ and $467 \mathrm{~m} / \mathrm{z}$ corresponds to $[\mathrm{M}-2 \mathrm{Na}+\mathrm{H}]^{-}$and $[\mathrm{M}-3 \mathrm{Na}+2 \mathrm{H}]^{-}$, respectively. Each of these ions was further fragmented with MS/MS analysis, and the data of characteristic product ions are summarized in Table 2.

ODP (m/z 325)

The oxidation of TA in the presence of visible light after $4 \mathrm{~h}$ has resulted in ODP. The ESI-Q-TOF spectrum of the ion at $\mathrm{m} / \mathrm{z} 325$ corresponds

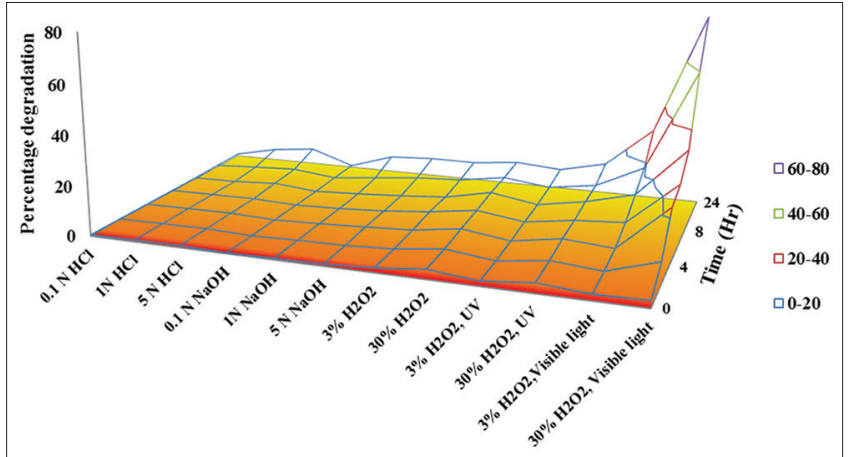

Fig. 2: Wireframe three-dimensional surface plot indicating the stability profile of tartrazine under various conditions

Table 2: MS/MS characterization of tartrazine (E102) in negative ion (NI) mode

\begin{tabular}{|c|c|c|}
\hline $\mathrm{m} / \mathrm{z}$ (Da) & MS & Fragment \\
\hline 467 & MS & {$[\mathrm{M}-3 \mathrm{Na}+2 \mathrm{H}]^{-}$} \\
\hline 263 & $\mathrm{MS}^{2}$ & {$\left[\mathrm{M}-2 \mathrm{NaSO}_{3}-\mathrm{COONa}+2 \mathrm{H}\right]^{-}$} \\
\hline 170 & $\mathrm{MS}^{3}$ & {$\left[\mathrm{M}-2 \mathrm{NaSO}_{3}-\mathrm{COONa}-\left\langle\mathrm{O}-\mathrm{NH}_{2}+2 \mathrm{H}\right]^{-}\right.$} \\
\hline 489 & MS & {$[\mathrm{M}-2 \mathrm{Na}+\mathrm{H}]^{-}$} \\
\hline 329 & $\mathrm{MS}^{2}$ & {$\left[\mathrm{M}-2 \mathrm{NaSO}_{3}+\mathrm{H}\right]-$} \\
\hline 236 & $\mathrm{MS}^{3}$ & {$\left[\mathrm{M}-2 \mathrm{NaSO}_{3}-\mathrm{O}-\mathrm{NH}_{2}+\mathrm{H}\right]^{-}$} \\
\hline 511 & MS & {$[\mathrm{M}-\mathrm{Na}]^{-}$} \\
\hline 467 & $\mathrm{MS}^{2}$ & {$[\mathrm{M}-\mathrm{COONa}]^{-}$} \\
\hline 261 & $\mathrm{MS}^{3}$ & {$\left[\mathrm{M}-2 \mathrm{NaSO}_{3}-\mathrm{COONa}\right]^{-}$} \\
\hline 168 & $\mathrm{MS}^{4}$ & {$\left[\mathrm{M}-2 \mathrm{NaSO} 3-\mathrm{COONa}-(\mathrm{O}) \mathrm{NH}_{2}\right]^{-}$} \\
\hline
\end{tabular}

MS: Mass spectrometer

to the $[\mathrm{M}-\mathrm{H}]^{-}$of ODP (Fig. 3d and e). Its mass could be attributed due to the cleavage of sulphonic acid groups at 6-, 18- positions and simultaneous hydroxylation at 8-position of TA. The MS of ODP showed a characteristic $[\mathrm{M}-\mathrm{COOH}]^{-}$ion at $\mathrm{m} / \mathrm{z} 281$, which indicates the loss of carboxylic acid group $(\mathrm{COOH})$ from $\mathrm{m} / \mathrm{z} 325$. The spectrum included abundant product ions at m/z 255 (loss of CO from m/z 281) and m/z 241 (loss of methyl group from $\mathrm{m} / \mathrm{z} 255$ ). In addition, the spectrum included high abundant ions at $\mathrm{m} / \mathrm{z} 191$ (loss of cyclobutadiene moiety from $\mathrm{m} / \mathrm{z}$ 241). Based on the above-discussed fragmentation pattern and elemental composition of ions (parent and product) along with HR MS data confirms the proposed structure for ODP (Fig. 4 and Table 3) and was identified as 2,5-dihydroxy-1-phenyl-3-(phenyldiazenyl)-2,3dihydro-1H-pyrazole-4-carboxylic acid.

\section{DISCUSSION}

The objective of this study is to separate TA from their degradation products, to isolate the degradation product by semipreparative HPLC method and to elucidate the plausible structure of the degradant and the degradation pathway by using HR-MS Analysis. A Kinetex $\mathrm{C}_{18}(150 \times 4.6 \mathrm{~mm}$, id, $5 \mu \mathrm{m})$ was used for the separation with mobile phase consisting of water and acetonitrile in an isocratic mode $(50: 50 \%, \mathrm{~V} / \mathrm{V})$ pumped through the column at a flow rate of $1.0 \mathrm{~mL} /$ minutes with an injection volume of $20 \mu \mathrm{L}$. The eluents were monitored at $426 \mathrm{~nm}$. The retention time of TA and the degradation impurity were found to be 3.4 and 2.45 minutes, respectively. The method was validated as per ICH guidelines for various parameters via accuracy, precision, sensitivity, selectivity, specificity, LOD, LOQ, robustness, and ruggedness. For TA, good linearity was observed in the concentration range of $4-100 \mu \mathrm{g} / \mathrm{mL}$. A $\%$ coefficient of variation $<2$ for the accuracy and precision studies demonstrated that the method was accurate and precise. When TA was subjected to various degradation conditions like hydrolysis, oxidation and exposure to UV and visible light, it was observed that the drug was stable under hydrolysis. But considerable degradation was observed in the presence of UV and visible radiation under oxidative conditions. The degradation impurity 


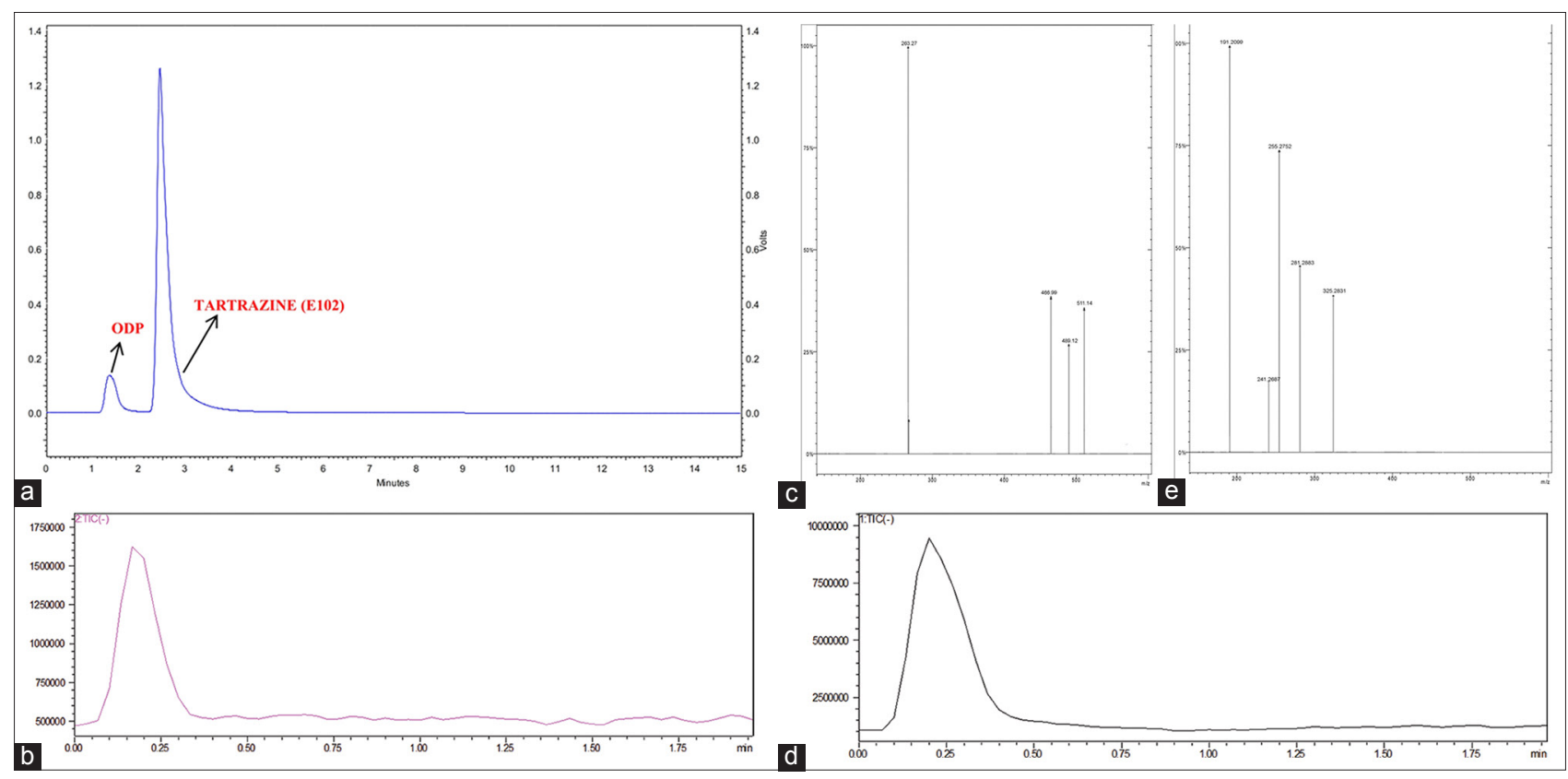

Fig. 3: High-performance liquid chromatography-diode array detector and liquid chromatography-quadrapole-time of flight analysis of E102 and one degradation product (ODP); (b) total ion current of E102 in NI mode; (c) mass spectrum of E102 in NI mode; (d) TIC of ODP in NI mode; (e) mass spectrum of ODP in NI mode

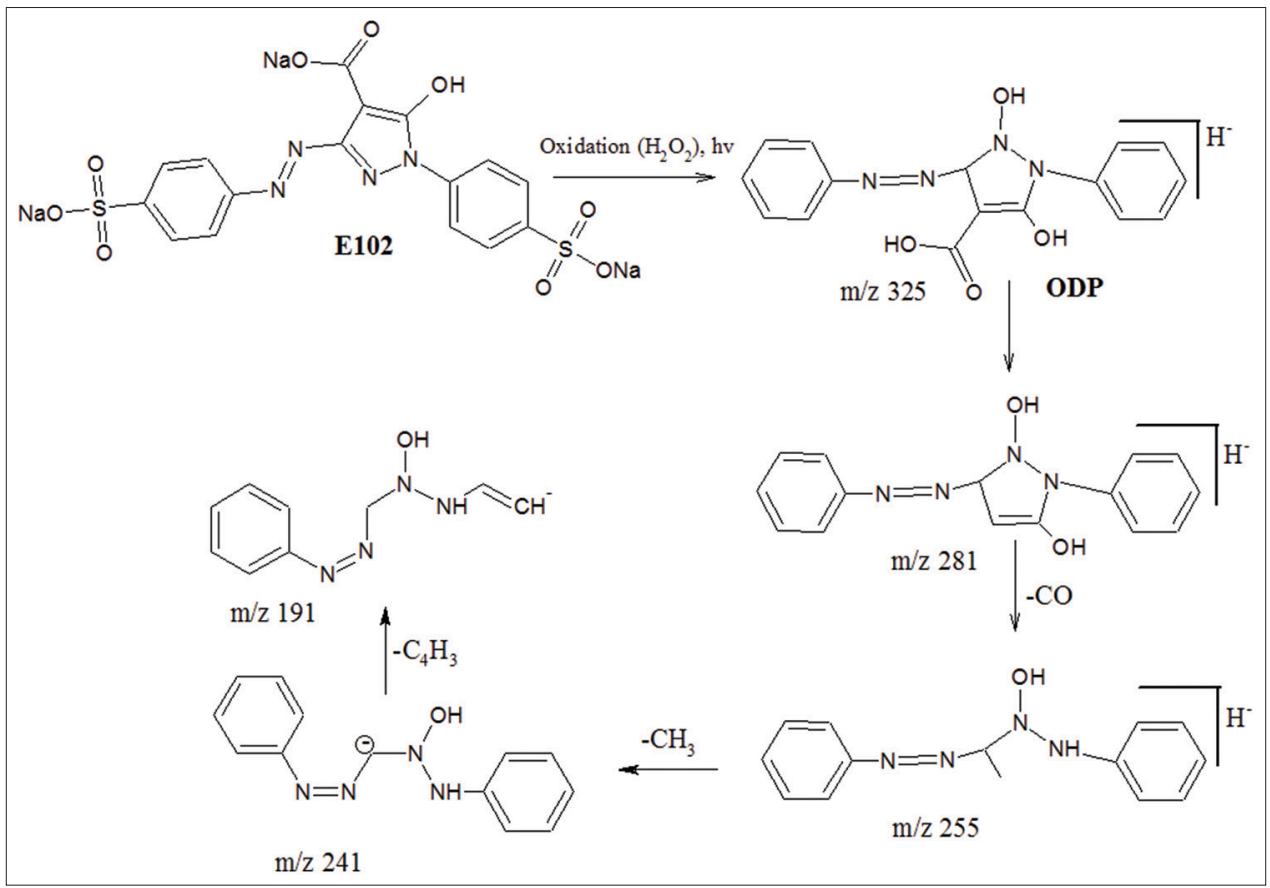

Fig. 4: Proposed fragmentation mechanism of [M-H]- ion of one degradation product

Table 3: Elemental compositions of ODP in MS ${ }^{\mathrm{n}}$ and HR MS spectral studies

\begin{tabular}{llllll}
\hline Analyte & Accurate mass (Da) & Proposed formula & Calculated mass (Da) & RDB & MS error (ppm) \\
\hline ODP & 325.2831 & $\mathrm{C}_{16} \mathrm{H}_{14} \mathrm{~N}_{4} \mathrm{O}_{4}^{-}$ & 325.2848 & 12 & 5.22 \\
& 281.2883 & $\mathrm{C}_{15} \mathrm{H}_{14} \mathrm{~N}_{4} \mathrm{O}_{2}^{-}$ & 281.2888 & 11 & 1.77 \\
& 255.2752 & $\mathrm{C}_{14} \mathrm{H}_{16} \mathrm{~N}_{4} \mathrm{O}^{-}$ & 255.2732 & 9 & -7.83 \\
& 241.2687 & $\mathrm{C}_{13} \mathrm{H}_{14} \mathrm{~N}_{4} \mathrm{O}_{4}^{-}$ & 241.2690 & 9 & 1.24 \\
& 191.2099 & $\mathrm{C}_{9} \mathrm{H}_{12} \mathrm{~N}_{4} \mathrm{O}_{4}^{-}$ & 191.2103 & 6 & 2.09 \\
\hline
\end{tabular}

RDB: Number of rings-double bond, ppm: Parts-per-million, ODP: One degradation product, MS: Mass spectrometer, HR: High-resolution

(ODP) eluting at $\mathrm{R}$ of 2.45 minutes was well resolved from TA. This was isolated by using a Zorbax semipreparative column. The isolated component was vacuum dried and subjected to HR-MS analysis for the plausible structural elucidation. Based on the fragmentation 
pattern of ODP from their $\mathrm{MS}^{\mathrm{n}}$ studies, the ODP may be identified as 2,5-dihydroxy-1-phenyl-3-(phenyldiazenyl)-2,3-dihydro-1H-pyrazole4-carboxylic acid.

\section{CONCLUSIONS}

The aim of this study was to evaluate the stability of TA by a validated HPLC method. The proposed method allows the separation of TA from its degradation product. The results confirm that TA dye gradually discolors in visible light under oxidative environment after $4 \mathrm{hr}$. On the other hand, the degradation product formed on irradiation of standard solutions containing $\mathrm{TA}$, revealed same retention time.

Further, the formed degradation product was isolated by semipreparative HPLC and characterized using high-resolution MS/MS. The accurate mass measurements obtained from HR-MS data were used to identify the unknown degradation product and to predict the degradation pathway of TA. There is no toxicity information available on the formed degradation species.

\section{REFERENCES}

1. Timberlake CF, Bridle P, Walford F. Developments in Food Colors. $1^{\text {st }}$ ed. London: Applied Science; 1980.

2. Ahlstrom LH, Eskilsson CS, Bjorklund E. Determination of banned azo dyes in consumer goods. Trends Anal Chem 2005;24(1):49-56.

3. Shimada C, Kano K, Sasaki YF, Sato I, Tsudua S. Differential colon DNA damage induced by azo food additives between rats and mice. J Toxicol Sci 2010;35(4):547-54

4. Government Printing Office. Code of Federal Regulations, Title 21, Parts 73, 74, and 82 and Section 101. 22(K). Washington, DC, US: Government Printing Office; 2012.

5. European Community Regulation (EC) No. 1333/2008 of the European Parliament and of the Council of Food Additives. 16, December; 2008.

6. Food Safety and Standards Authority of India (FSSAI) Regulation No. 2-15015/30/2010 of Ministry of Health and Family Welfare of Food Products Standards and Food Additives. 1 August; 2011.

7. Rowe KS, Rowe KJ. Synthetic food coloring and behavior; A dose response effect in double blind, placebo - Controlled, repeated measures study. J Pediatr 1994;125:691-8.

8. Ardern K, Ram FS. Tartrazine exclusion for allergic asthma. Cochrane Database Syst Rev 2001;4:CD000460.

9. Geundouz M, Mehedi N, Zaoui C, Saidi D, Kheroua O. Immune response after tartrazine subchronic ingestion in Swiss albino mice. Int J Pharm Pharm Sci 2013;5(2):584-92.

10. Gottlieb A, Shaw C, Smith A, Wheatley A, Forsythe S. The toxicity of textile reactive azo dyes after hydrolysis and decolourisation. J Biotechnol 2003;101(1):49-56.

11. Sorouraddin MH, Rostami A, Saadati M. A simple and portable multicolor light emitting diode based photocolourimeter for the analysis of mixtures of five common food dyes. Food Chem 2011;127:308-13.

12. de Andrade FI, Florindo Guedes MI, Pinto Vieira ÍG, Pereira Mendes FN, Salmito Rodrigues PA, Costa Maia CS, et al. Determination of synthetic food dyes in commercial soft drinks by TLC and ion-pair HPLC. Food Chem 2014;157:193-8

13. Ramakrishnan SP, Lakshmi JB, Surya PR. Estimation of synthetic colorant tartrazine in food stuff and formulations and effect of colorant on the protein binding of drugs. Indian J Pharm Ind Res 2011;1(2):141-52.

14. Huang HY, Chuang CL, Chiu CW, Chung MC. Determination of food colorants by micro emulsion electrokinetic chromatography. Electrophoresis 2005;26(4-5):867-77.

15. Wu H, Guo JB, Du LM, Tian H, Hao CX, Wang ZF, et al. A rapid shaking-based ionic liquid dispersive liquid phase microextraction for the simultaneous determination of six synthetic food colourants in soft drinks, sugar-and gelatin-based confectionery by high-performance liquid chromatography. Food Chem 2013;141(1):182-6.

16. Shen Y, Zhang X, Prinyawiwatkul W, Xu Z. Simultaneous determination of red and yellow artificial food colourants and carotenoid pigments in food products. Food Chem 2014;157:553-8

17. Kaur A, Gupta U. Identification and determination of binary mixtures of synthetic dyes with $\mathrm{Cr}$ (III) complex in food stuffs and pharmaceutical samples by high performance liquid chromatography. Indian J Pharm Sci Res 2014;4(1):49-52.

18. Wittmer DP, Nuessle NO, Haney WG Jr. Simultaneous analysis of tartrazine and its intermediates by reversed phase liquid chromatography. Anal Chem 1975;47(8):1422-3.

19. Behnajady MA, Modirshahla N, Hamzavi R. Kinetic study on photo catalytic degradation of C.I. Acid yellow 23 by $\mathrm{ZnO}$ photo catalyst. J Hazard Mater 2006;133:226-32.

20. Rao KV, Lavédrine B, Boule P. Influence of metallic species on $\mathrm{TiO} 2$ for the photo catalytic degradation of dyes and dye intermediates. J Photo Chem Photo Biol A 2003;154:189-93.

21. Gianotti V, Angioi S, Gosetti F, Marengo E, Gennaro MC. Chemometrically assisted development of IP-RP-HPLC and spectrophotometric methods for the identification and determination of synthetic dyes in commercial soft drinks. J Liq Chromatogr Relat Technol 2005;28:923-37.

22. Gosetti F, Chiuminatto U, Mazzucco E, Mastroianni R, Marengo E. Ultra-high-performance liquid chromatography/tandem highresolution mass spectrometry analysis of sixteen red beverages containing carminic acid: Identification of degradation products by using principal component analysis/discriminant analysis. Food Chem 2015;167:454-62.

23. Gosetti F, Chiuminatto U, Mazzucco E, Calabrese G, Gennaro MC, Marengo E. Identification of photodegradation products of Allura Red AC (E129) in a beverage by ultra high performance liquid chromatography-quadrupole-time-of-flight mass spectrometry. Anal Chim Acta 2012;746:84-9.

24. Gosetti F, Chiuminatto U, Mazzucco E, Calabrese G, Gennaro MC, Marengo E. Non-target screening of Allura Red AC photodegradation products in a beverage through ultra-high performance liquid chromatography coupled with hybrid triple quadrupole/linear ion trap mass spectrometry. Food Chem 2013;136:617-23.

25. Gosetti F, Frascarolo P, Mazzucco E, Gianotti V, Bottaro M, Gennaro MC. Photodegradation of E110 and E122 dyes in a commercial aperitif. A high performance liquid chromatography-diode arraytandem mass spectrometry study. J Chromatogr A 2008;1202(1):58-63.

26. Gosetti F, Gianotti V, Angioi S, Polati S, Marengo E, Gennaro MC. Oxidative degradation of food dye E133 Brilliant Blue FCF Liquid chromatography-electrospray mass spectrometry identification of the degradation pathway. J Chromatogr A 2004;1054(1-2):379-87.

27. Gosetti F, Gianotti V, Mazzucco E, Polati S, Gennaro MC. Sunlight induced degradation of E133 in a commercial beverage. Dyes Pigments 2007;74:424-32

28. Gosetti F, Gianotti V, Polati S, Gennaro MC. HPLC-MS degradation study of E10 Sunset Yellow FCF in a commercial beverage. J Chromatogr A 2005;1090(1-2):107-15.

29. Antakli S, Nejem L, Katran S. Simultaneous determination of tartrazine and Brilliant Blue in foods by spectrophotometric method. Int J Pharm Pharm Sci 2015;7(6):214-8.

30. Veni NK, Meyyanathan SN, Babu BN, Sharma AK, Srikanth BA, Sathyam AB, et al. Simultaneous estimation of colorants sunset yellow and tartrazine in food products by RP HPLC. Int J Res Pharm Sci 2011;2(4):545-9.

31. ICH. Validation of Analytical Procedures: Text and Methodology, Guideline Q2 (R1). Geneva: ICH; 2005. 